\title{
Identity Contestation of Contemporary Painting Art in Makassar
}

\author{
Muh. Faisal ${ }^{1 *}$, Supriadi Hamdat ${ }^{2}$, Muhammad Basir ${ }^{3}$, Halilintar Latief $^{4}$ \\ ${ }^{1}$ Department of anthropology, Graduate Program, University of Hasanuddin, Indonesia \\ ${ }^{2}$ Department of anthropology, University of Hasanuddin, Indonesia \\ ${ }^{3}$ Department of anthropology, University of Hasanuddin, Indonesia \\ ${ }^{4}$ Department of anthropology, University of Hasanuddin, Indonesia \\ *Corresponding Author: muhfysal@gmail.com \\ DOI: $10.31364 / \mathrm{SCIRJ} / \mathrm{v} 6.16 .2018 . P 0618534$ \\ http://dx.doi.org/10.31364/SCIRJ/v6.i6.2018.P0618534
}

\begin{abstract}
This study was intended to describe the identity and practices of painting art through the struggle and identity contestation among artists in Makassar. It is characterized by symbolic diversity in painting art as the manifestation of artist identity. In collecting the data, the researcher used participant-observation by applying ethnographic approaches, especially at art exhibition moments such as the Makassar Biennale, and other art exhibitions held by Makassarese artists. Pierre Bourdieu's theory of habitus, capital, and arena became one of the theoretical approaches that researcher used to describe the social practices in the field of fine art in Makassar. The objectives achieved in this study were classified based on the knowledge system, institutional system, and economic system practiced by Makassarese artists. The results of this study revealed that the ideological knowledge of artists was closely related to the symbolic knowledge created through the painting art. The work of art was created on the basis of personal function which tends to be mimetic; while painting art which was created based on social function has two aspects, namely idealism (social realism) and profit (imitationalism). Furthermore, work of art was created based on physical function which tends to present works of art mix media and artwork use (craft). The concepts were practiced based on the contestation of artists in presenting the discourse of contemporary fine art in Makassar. Based on the results of this study, it was found that the identity politics of Makassarese artists were not fully separable from economic politics, in which there was a process of artistic diffusions through discourse and symbolic system among artists that have been segmented through institutions, agencies and other socio-economic classes.
\end{abstract}

Keywords: Contestation, Identity, Visual Arts, and Contemporary Art Discourse

\section{Introduction}

The artistic phenomenon in Makassar, (especially in the field of fine art) is always related to ideological differences in constructing an identity. In this context; it covers the art identity of individual as well as the art identity of group. The identity difference is then manifested through the diversity of the artwork which creates symbolically. It is similarly with the presence of the tendency of the dichotomy between artistic groups, such as academic and non-academic artists (autodidact), although this labeling basically requires a clear proposition. When referring to Salam's note [1], the dichotomy has already appeared since the arrival of the art institution. Another thing can be seen from the tendency of the presence of the influence of expressionistic ideas that affect the practice of painting art in the Fine Art Department of IKIP Ujung Pandang which was no longer faithful to use naturalist-realistic language that was found in non-academic artists' works in the 1970s.

The identity difference among artists is not only seen from the struggle between academic and autodidact artists. The art identity difference also occurs individually on fellow academic artists which appears their own competition. Similarly, the identity difference among autodidact artists is also a contest space that cannot be avoided in the artistic phenomenon in Makassar.

This study was started from the characteristics differences of the artists' knowledge that the researcher got through art events and the struggles among artists as a way of finding new identities. Furthermore, the new identity is present in the development of the latest art which cannot be separated by anthropological studies related to the value aspect of ideological knowledge and human practices as a symbolic system bound by the cultural phase. The theory of the knowledge reproduction is called the process of habitus formation that is influenced by the human knowledge and mental system [2]. While the development of advanced art culture in Makassar refers to the development of contemporary art in Indonesia, which was present since 1975. Such a phenomenon is certainly inseparable from the contemporary paradigm that always offers totalize, globalization and the universalism of human knowledge which tends to form homogeneous behavior, which is called meta-narrative [3].

Therefore, the art contestation that was described in this study was a description of the process of art dialectics among artists that always starts from an ideological understanding which then forms the art practices especially in Makassar. In practice, however, it cannot be separated by the diffusion process (diffusion values) that comes through artistic practice between local artists and the foreigner artists. 
Referring to the description above, then this study tried to obtain information in the field of fine arts in relation to cultural events as a symbolic system. Art as a component in culture, or sub-system of culture, can clearly be seen its function in human life. According to Geertz and Suparlan in [4], art as a the culture result is a guide of life for proponent communities in conducting its activities; which contains the cognitive models, symbolic systems, or the giving of meaning that is entirely connected in historically transmitted symbols.

\section{Methodology}

This study was the descriptive qualitative research; the type of research depends on the focus of the problem researched. In this case, it aimed to reveal the identity and existence of contemporary artists in Makassar which cannot be separated by politics identity. Therefore, ethnographic research was more relevant by using a qualitative descriptive approach. This study focused on the visual art aspect, which is covered by ideological principle as a form of value system in the life of Makassar City, but in its assessment, it cannot be separated in various aspects of community life, such as belief/religious system, science, language, livelihoods, social organization and technology system. This was mentioned as an extra aesthetic approach [5].

Furthermore, as a qualitative research, this study was more emphasis on the process than on the results. Because this study emphasized on the process, so the priority was not only the relationship between the informants and the researcher, but also the relationship between the researcher and the work of arts was also constructed based on the symbolic interpretation method. Therefore, data collection techniques were conducted in accordance with the following classifications: Observation, in-depth interviews, Documentation (recording and noting). Data analysis techniques used Spradley's model [6], i.e., doing domain analysis or determine the category after obtaining a general and comprehensive description of the research object. The selected domain was further elaborated into more detailed taxonomic analysis to understand its internal structure. In this study, the taxonomic analysis classified the structure of fine arts, such as painting, sculpture, installation art and design art that has a connection to contemporary life in Makassar.

\section{Results}

\subsection{Knowledge System/Artistic Ideology}

Painting art was the most popular art in Makassar since the colonial period of the 1940s. If we are talking about art in Ujung Pandang (read: Makassar), it usually refers to painting art. This popularity which makes it so developed not only in Indonesia, but especially in the field of art education; although the opposite is also very likely, that its rapid development has made it more popular than other types of art. Among the famous Indonesian artists, as much as the researcher known, there are the number of names of famous Indonesian painters including the most after the names of writers and poets. In addition, the discussions about painting art dominate a fairly serious discourse about arts, including in the field of art education in Makassar at the time.

If it is described symbolically, painting art works are influenced by academic processes, the painting art works are dominant characterized by naturalist-realistic (mimesis-imitationalism) of imitation of objects-things. It means that the works of art are created based on the concept of mimetic, i.e., in the form of authentic imitation directed to the suitability of visual objects around, in this case this refers to the imitation of nature, including human as a whole complexity of nature. However, the flow of naturalist-realist art works is allegedly present since the colonialization of the Japanese nation through watercolor [1]. It is similarly with the presence of art education programs in IKIP Ujung Pandang in 1970, which confirmed the teaching of art through the practice of natural-realist arts or mimetic concepts. The same thing is shown by the people of South Sulawesi through the way they appreciate the works of art that glorifies the realists works.

The above description explains that mimesis art events including in Makassar closely related to where the cultural system in human life formed at certain times, especially the paradigm of art oriented to teaching and education. Therefore, the mimetic way of drawing that the researcher emphasized in this study was the concept of mimetic as imitation, authentic imitation, as a reflection of society towards the reality.

In line with the above context, the development of South Sulawesi art in particular is almost always associated with art education or arts education institutions, starting at the level of basic education, secondary education and higher education. This means that the artistic phenomenon of South Sulawesi is closely related to the quality and quantity of art education providers. The art education paradigm is then gradually formed a system of community values in dealing with the arts. 


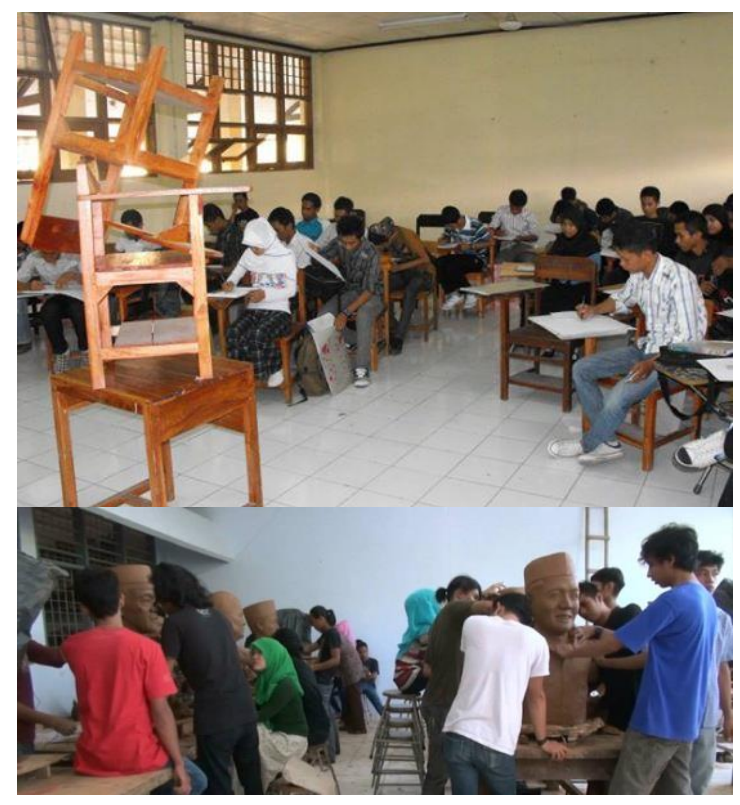

Figure 1.The Situation of Imitation (Mimetic)-Based Course Practices at Art Education Colleges in Makassar

To find out how the system of episteme was institutionalized in the artistry of South Sulawesi, the researcher further elaborated some of the practical descriptions of the organization and the institutional system of fine arts in South Sulawesi as described in Table 1.

Table 1. The Fine Art Institutional Trilogy of South Sulawesi

\begin{tabular}{llll}
\hline No & \multicolumn{1}{c}{ University - Art School } & Art Organization-Agency & Art Community-Studio \\
\hline 1. & It is based on formal education & It is based on the art program & $\begin{array}{l}\text { It is based on creative } \\
\text { practices }\end{array}$ \\
\hline $2 .$. & $\begin{array}{l}\text { It is majority oriented towards art } \\
\text { education (art teachers as output) }\end{array}$ & $\begin{array}{l}\text { It is oriented to the } \\
\text { presentation of art programs }\end{array}$ & $\begin{array}{l}\text { It is oriented to the } \\
\text { creation of artworks }\end{array}$ \\
\hline 3. & It refers to the national curriculum & It refers to the work program & $\begin{array}{l}\text { It refers to needs and } \\
\text { requests }\end{array}$ \\
\hline 4. & $\begin{array}{l}\text { It prepares students who are } \\
\text { qualified in the field of art, } \\
\text { independent and ready to use }\end{array}$ & $\begin{array}{l}\text { It requires arts } \\
\text { professionalization }\end{array}$ & $\begin{array}{l}\text { It presents art } \\
\text { productivity }\end{array}$ \\
\hline 5. & $\begin{array}{l}\text { Concepts and theories are as } \\
\text { patrons }\end{array}$ & Visionary is as a patron & $\begin{array}{l}\text { Experimentation and } \\
\text { field are as patron }\end{array}$ \\
\hline 6. & $\begin{array}{l}\text { Recruitment is based on } \\
\text { competence standards and artistic } \\
\text { qualifications }\end{array}$ & $\begin{array}{l}\text { Recruitment is based on } \\
\text { artistic professionalism } \\
\text { standard }\end{array}$ & $\begin{array}{l}\text { Recruitment is based on } \\
\text { interests and talents }\end{array}$ \\
\hline 7. & It has periodic period & $\begin{array}{l}\text { Its base is based on emotional } \\
\text { closeness }\end{array}$ & $\begin{array}{l}\text { Its periodic period is not } \\
\text { specified }\end{array}$ \\
\hline
\end{tabular}

Furthermore, the classification also shows the fundamental differences between fellow art colleges, especially universitybasedarts education (UNM and Unismuh) and non-educational/fine arts (IKM and ISBI), as well as vocational schools of art $(S M K I)$ and public school (SMA).Another difference is also shown in art communities and art studios that simply affirm significant segmentation. It can be described as follows: 


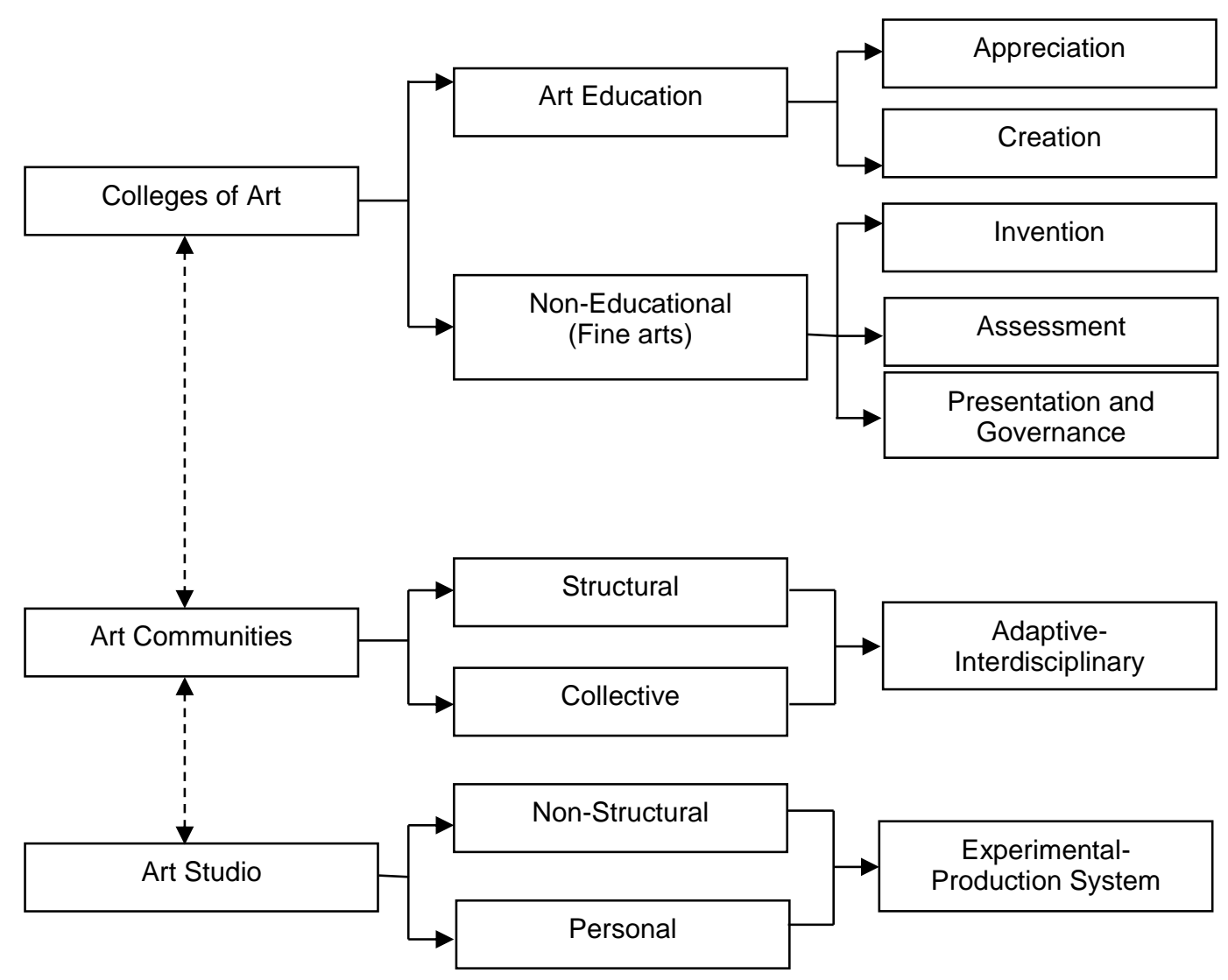

Figure 1.Taxonomy of Fine Art Institutionalization

\subsection{Identity Segmentation}

Through the categorization of art identity, Rohidi [5] wrote it in a national seminar paper entitled "Segmentation of Identity in the Field of Fine Arts", which was mentioned that the identity of art can be classified into three aspects, namely the identity of individual arts, identity of group arts and identity of the archipelago arts. Based on those three identity forms, then the researcher described them based on the categorization in South Sulawesi arts constellation as follows:

1. The identity of individual arts, which is primarily seen as a characteristic of either being congenital birth or formed by a person's life history which allows the growth of personal preferences so that the basic classification and characteristics can be distinguished from others. Individual identity can be at either the level of values or norms that serve as the artistic guideline, the ranking of the creation process, or at the level of artwork [5].

Then, the researcher tried to describe the identity differences inherent in works of fine art in Makassar. This means that the differences of work identity is a necessity that allows the formation of diversity as well as a property of art appreciation that supports the development of art at the discourse level. But the struggle and the seizure of symbolic power then occur when among art individuals dominate each other. In this case, it deals with how the diversity of art styles competes to get the mutual position in fascinating and gaining the public appreciation.

2. While at the level of group arts, identity indicates the following characteristics, namely (1) it is a group idea, (2) it is the idea of group citizens whose thought theme or form contains group characteristics; (3) it is also the idea of group members who by as many members as possible the other groups concerned are so highly rated that they can be the pride of all of them, and thus they are willing and able to identify themselves with the art, and (4) the recognition of other people or groups in the context of their social interaction. The identity of group art is evident in the form of ideas reflected in the process of creation and the form of the work [7].

In this case, the diversity of the identity of group arts in South Sulawesi is characterized by an organizing, institutionalizing, grouping, and art community system, which each has the above characteristics. This identity is always present in displaying certain characteristics that distinguish it with other group arts. In Makassar, this identity is then at stake through symbolic ideas in works of art, as well as the concept and form of artistic representation of arts ideologically. Although in every citizen group has different identity of individual art, but the difference is always bound by group identity. This is what then to be described in the next discussion. 
3. Furthermore, the identity of the archipelago arts as part of a potential culture to strengthen and develop the cultural heritage of "Nusantara (Archipelago)". This art is a clear manifestation in showing the identity of a nation that has the cultural nobility, both formed due to historical processes and existing environmental resources and can be utilized today.

The development of the contemporary fine arts shows that the identity of the archipelago is then at stake between the diversity of culture and the progress of contemporary art demands attract each other. The modern art as a consequence of the great narrative (globalization, universalism) makes the identity of archipelago arts (small narrative) re-discussed. In this case, the discussion of identity as stated by Piliang [8] is one of the central themes in relation to the development of globalization in art, economy and information. As a key word in the contemporary politics, it is given a different connotation, so it seems as if talking about things that are not similar. In Indonesia, for example, the discussions about identity are linked to fears of the disintegration of nationalism and national identity. While on a global scale, the discussion of identity in the current pluralism era becomes increasingly complex, because it is not only contested from different political fronts (right side, left side, conservative), but also on the basis of different motivations. However, whatever the underlying motivation and from whatever front it is established, the identity only becomes an issue when it is in a critical situation; when something is considered steady, stable, and coherent is replaced by an experience full of doubt, uncertainty, and vagueness; when a generation consider seriously to what the previous generation inherited. In the field of art in Makassar, for example, the discourse of contemporary art can not be separated by global discourses of totality and universalism. The phenomenon is reinforced through the value deployment system that takes place rapidly. Through industrial devices, art divides into two parts, between conservative and art renewal, idealist and materialist, mimetic and expressionist artist, and so on. This shows that the underlying motivation is an ideological system that is fought for.

Furthermore, referring to the functional theory of B. Malinowski which is later translated into Feldman's [9] art concept, it classifies in three functions of art, namely: personal functions of art, the social functions of art, and the physical functions of art. Then the segmentation of identity can be described as follows:

1. Personal functions of art

It is a disclosure of all dimensions of the human personality, or psychological, and specific circumstances. Art is more than standard symbols and signs used because of the formation of art elements that include characteristics, gender, patterns, genre, etc. The existence of these elements gives intention and meaning to the audiences. Art interpersonally relates to themes, such as: the exposure of love, sex, marriage, and death, all reflecting on the personal function. Then, the identity of the individual is formed based on aesthetic experiences. The fundamental aesthetic pleasure may be called the thrill of recognition. Clearly, recognition always plays an important role in human survival, and can explain the popularity of art that is easily identifiable when recognizing something in a work of art, in a sense, practicing survival techniques, improve the ability to distinguish between friends and opponents.

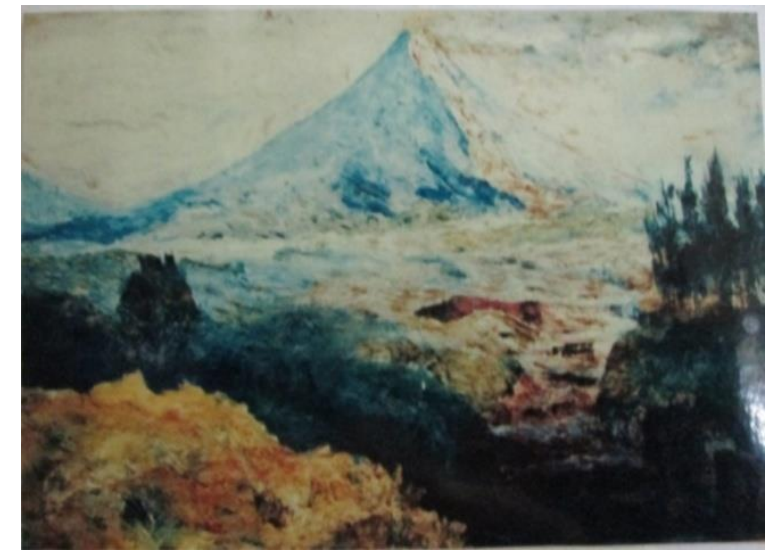

Figure 3. The work titled Merapi, Abdul Kahar Wahid Size 73 x $113 \mathrm{~cm}$. In 1973

Oil on Canvas 


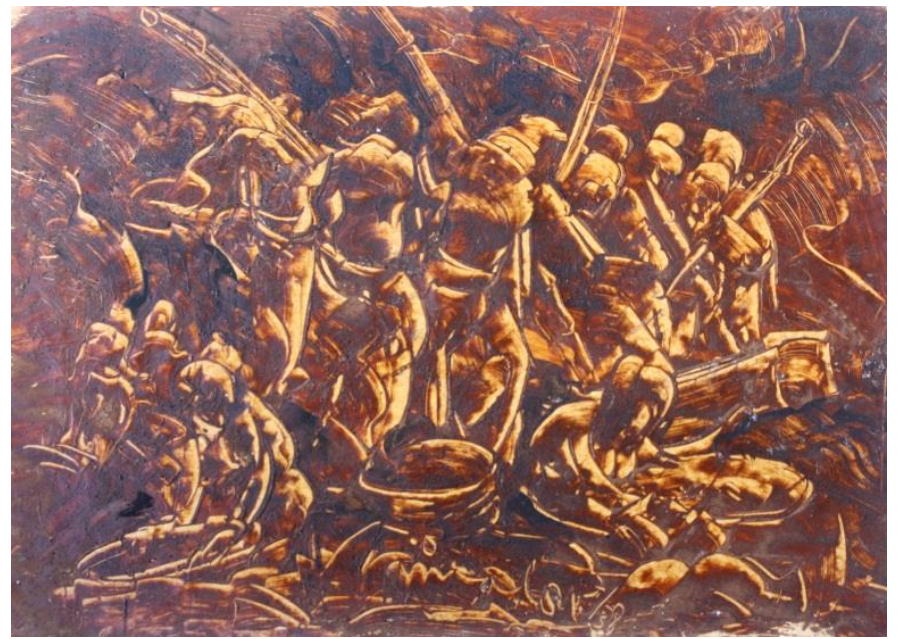

Figure 4. Zaenal Beta Expression Work in 1981

Title: Panen, 43 x $31 \mathrm{~cm}$

Clay on Paper

2. The social functions of art

In this case, art carried out the social functions through several things, such as: (1) influencing human groups; in terms of; these works that are created can encourage people's attention as well as respond to the works shown, (2) it is made to be seen or used in general situations, this can also be seen from some works of mural art and street art that contribute through artistic practices in public places; (3) describe aspects of common life as opposed to the kind of personal experience, such as it can be seen through the works that always show the values of kinship, togetherness, and other social values. In such situations, the involvement of the general public in art practices is demonstrated through an egalitarian participatory means.

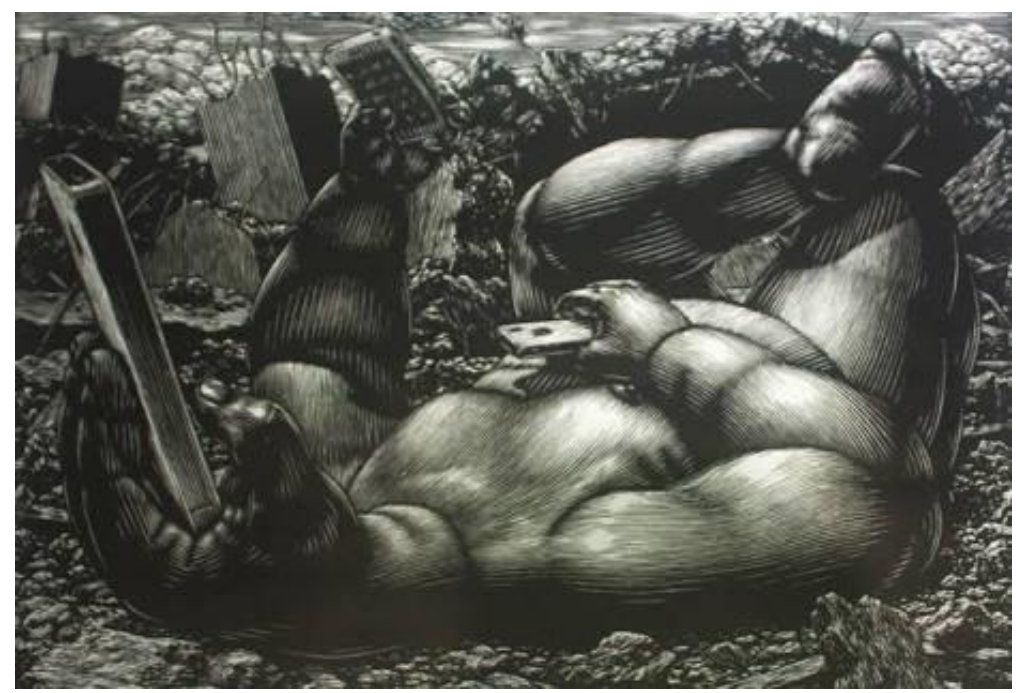

Figure 5. Title: 'Addiction', 55x72 cm

Wood Cut, 2013

(the $3^{\text {rd }}$ winner of Triennale International event) 


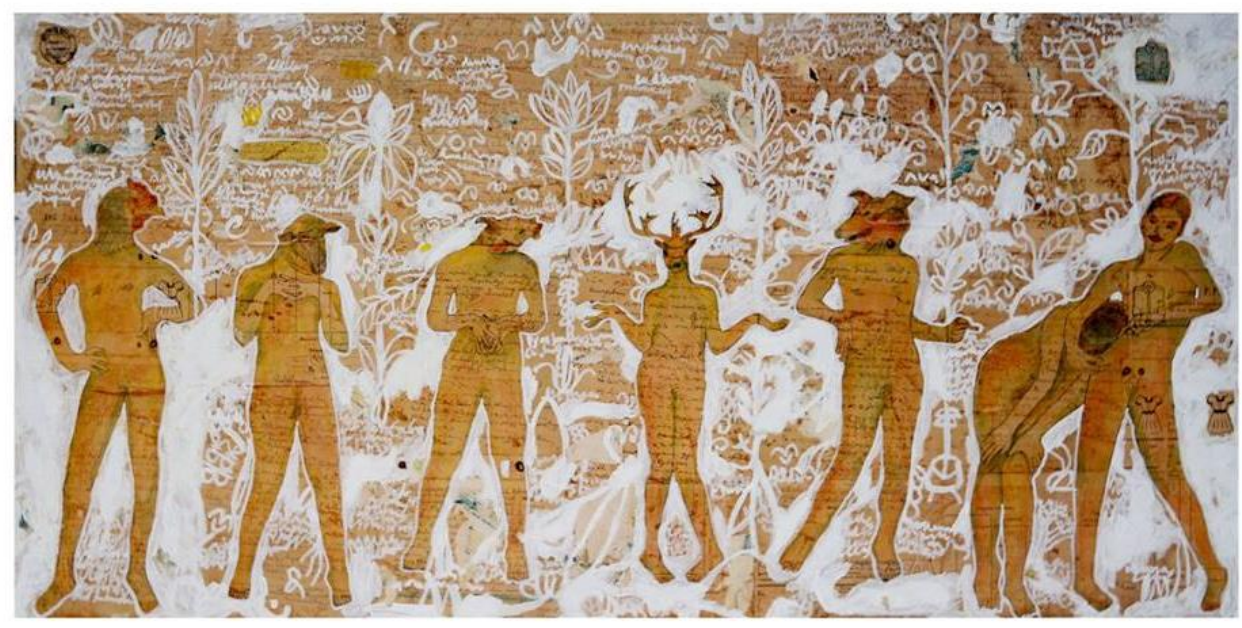

Figure 6. Title: Homo Homini Lupus

ZamKamil's Work

Oil on Canvas

3. The physical functions of art

The physical functions include the usage value or applied art. Art in the field of human life is shown through the use function, so that the physical function becomes very important, especially the development of industry today, one of them in Makassar. Art in relating to "physical functions" refers to objects made for use as a tool or facility. For example: in industrial designers, they create industrial objects, made and sold to consumers. Art is interconnected and responsible for the scope of the region or environment, both how it looks and how it works. And in this sense, art means more than decorating or beautifying in its basic sense.

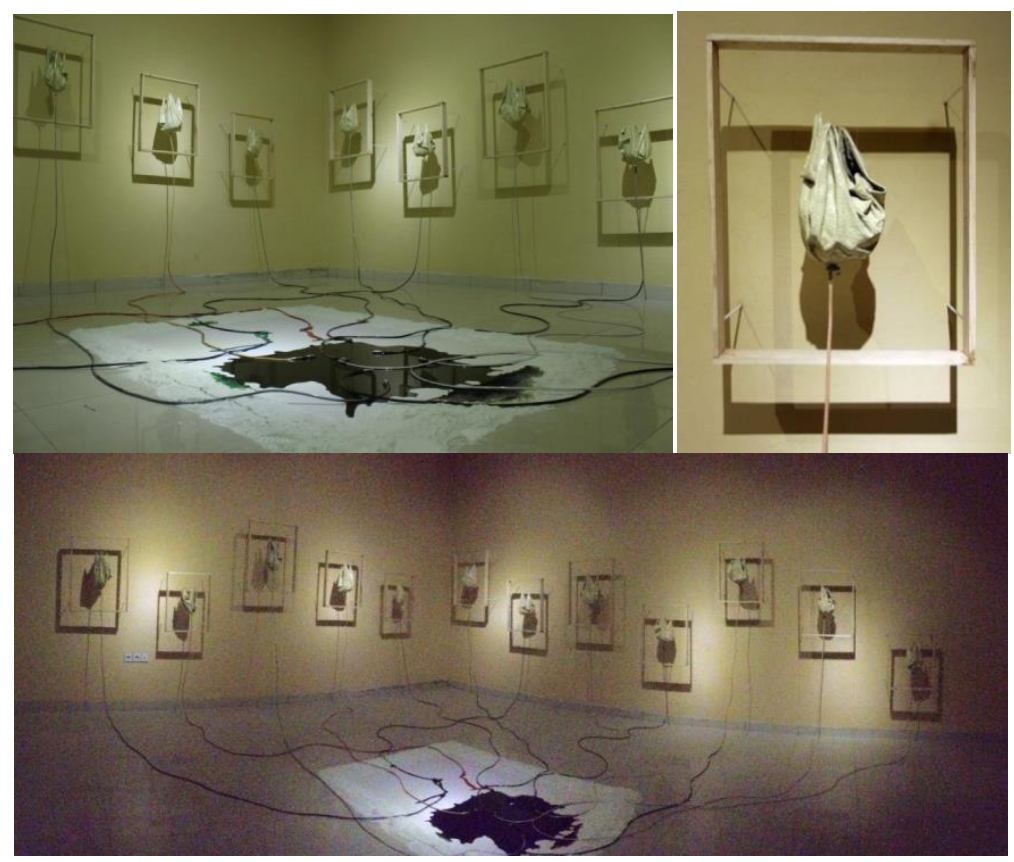

Figure 7.Title: "Bab Baru (DialektikaPengakuan)" Mix Media, Lenny Ratnasari Weichert's Work in 2015 

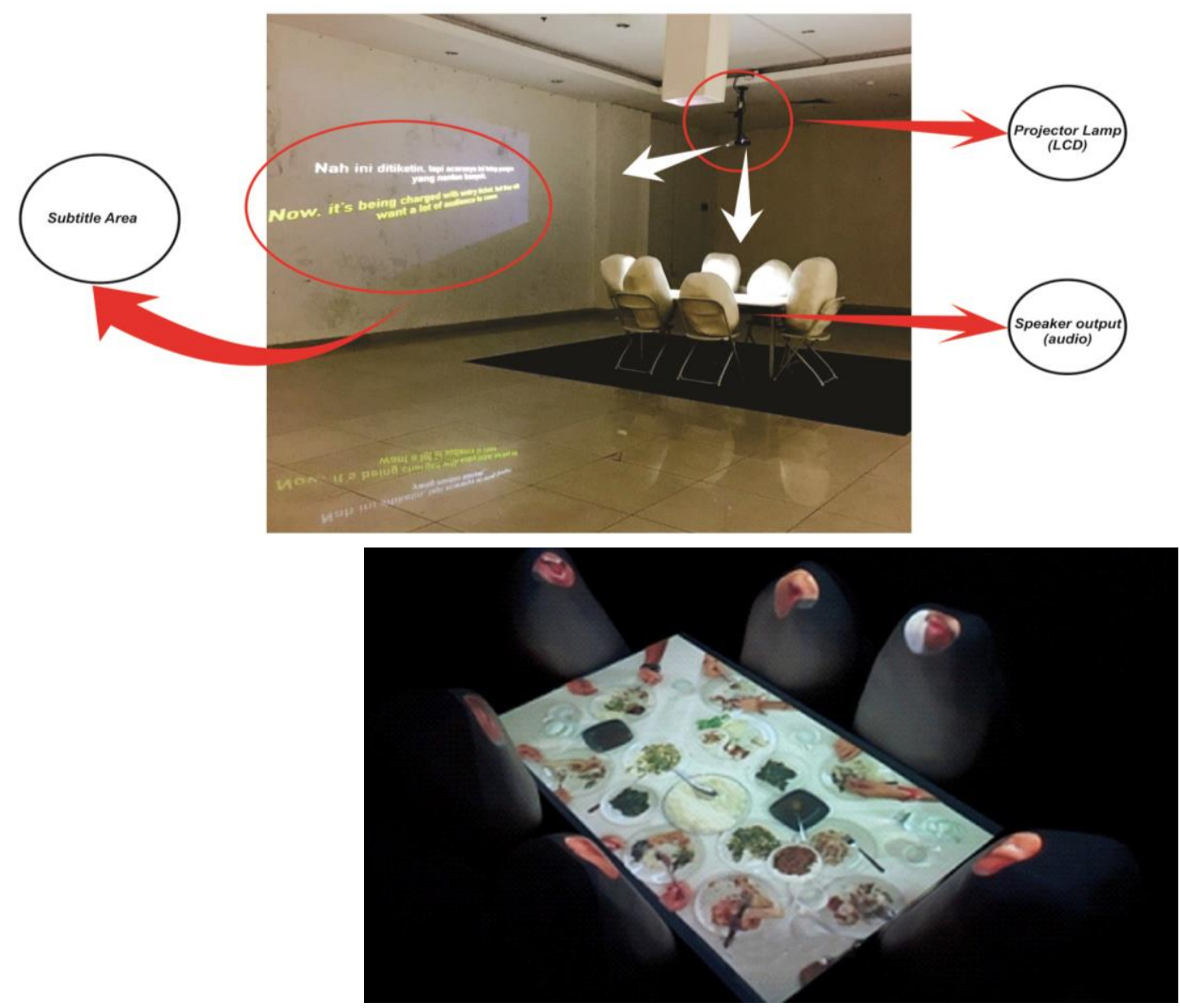

Figure 8.Title: PolitikMakanMalam

Video Installation Art Works; Jim Allen Abel, in 2015

It can be denied that the implications of economic capital have a major impact on the existence and representation system of artwork.It is similarly with the dichotomy among idealist artists and materialist artists which are familiar to Makassar's art practices, which is also a socio-economic phenomenon experienced by Makassarese artists. The habitus and capital system are two interrelated aspects of fighting over, defending and shaping social practices, in this case artistic practices. In the symbolic capital art practices not only can be seen from the symbols of education, status, and reputation of artists, but can also be seen from the symbolic markers presented in the artwork [2]. Therefore, from the explanation above, the symbolic contestation in artwork is shown through several aspects such as:

1. Symbolic contestation is influenced by the economic system, which shows the presence of different works of art that are profit oriented and non-profit oriented (idealist, discourse, meaning, interpretivisme).

2. The above-mentioned simplicity of artwork shows that symbolic contestation through artwork is not only seen from the use of symbolic network on the structure of works. However, the use of media tools and materials make the identity of the artwork experiences the significant differences.

3. The concepts and visual discourses presented are closely related to the habitus in which an artist is formed.

4. The symbolic idea is influenced by the artist's knowledge system which is then concretized through symbolic visualization in arts.

5. The creative practice is demonstrated through an ideological system of looking at and treating artworks.

The above simplicity shows that the ideological knowledge system embodies symbolic knowledge in a work of art. In the aesthetic idea, it shows there are two aspects which become the background of symbolic knowledge in the work of art, namely intra-esthetic and extra-esthetic. Intra esthetic is an art practice that emphasizes internal and fundamental aspects, such as emotions, expressions, skills, techniques, and other aspects related to the working procedure. The artistic skill and ability are determined by the appreciation of an artist's sensitivity. Further, extra aesthetic is a rationalization desire of art in interpreting the external reality within the artist. Art is no longer limited to the exoticism of visual forms, but rather to conceptual ideas in interpreting the phenomena of human life visually.

With respect to the reproductive system of knowledge, Bourdieu [10] affirms that agents always form structures, and vice versa structures always form agents. From this, the working culture is formed from the human cultural system.

To distinguish the ideas of intra esthetic and extra esthetic, it can be seen in the following diagram: 


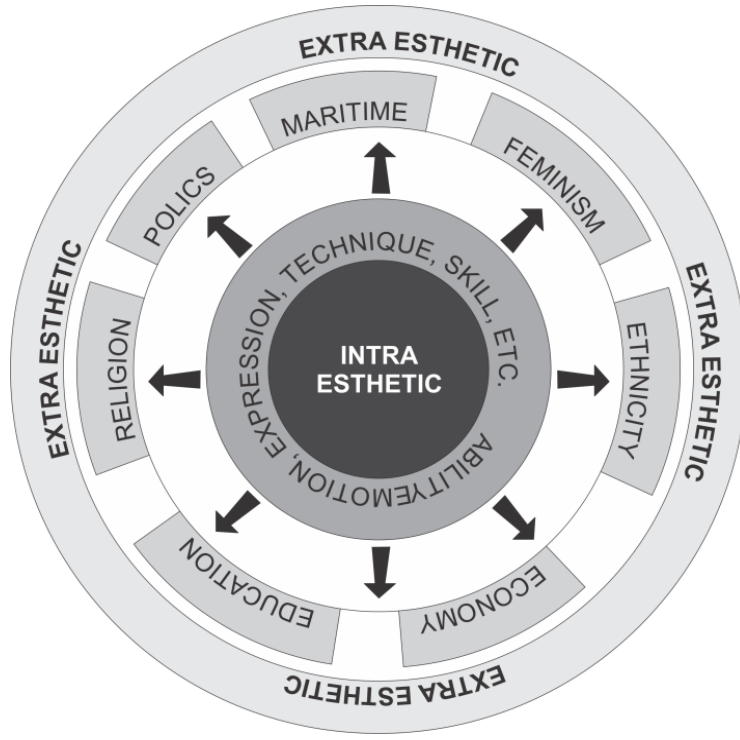

Figure 9. Intra Esthetic and Extra Esthetic Approaches

\section{Conclusion}

Based on the results of objective readings during this study, the researcher concluded that artists' contestation in this investigation includes an orientation of artists' achievement through art practices, while to present such practices, the knowledge, economic and cultural aspects become a discursive space within gain aesthetic vision. The aforementioned achievements in the aesthetic vision are then sourced from several aspects; the first aspect is presented from the intra esthetic (expression, emotion, feeling, and impulse of the internal subject) of the artists. Second, the aspects are presented based on extra esthetic, which is an aesthetic vision based on external spaces, such as social, education, politics, economy, culture, etc. Third, the aspect is built on the relationship between intra and extra esthetic. From the diversity of aesthetic vision, then the identity differences become a necessity in the fine art contest space, especially in South Sulawesi.

The contestation between artists can be described on the basis of the following background:

1. Knowledge system (episteme); it includes the contestation of art education and the art sciences in presenting the distinguishing markers in art works. Beyond that, the presence of interdisciplinary knowledge of the arts (literature, history, social, economics, etc.) also shows considerable stretch in conceptualizing extra-esthetic art. The encounter of the art episteme system shows the controversy of the fine art in the field of arts, especially in Makassar. Through such a system of knowledge, then art practices are cultural practices which cover the human experience shown in a work of art.

2. Economic system; this system has a considerable influence on the aesthetic ideas embodied in the artworks. It implies a symbolic notion that is concretized in a work of art. So there is a distinctive tendency between materialist-oriented work, and idealist-oriented work. In this context, the artistic system can not be separated from the flow of human needs that are at least in the vortex of industrialization of art. From the art of the network and the structure of power goes on at once created in building an established group-structure.

3. Symbolic system; the symbolic knowledge embodied through art, is the result of a representation of the ideological knowledge of the artist that is covered by two underlying aspects, i.e., the work embodied as a symbolic-interpretative system, through which the artist expresses him/herself empirically, explores the symbolic idea to produce depth and novelty in his/her works. Specifically, the symbolic network in the work contained discourse, message, and narration. The next is the work embodied based on the commercial aspect (follower). This work is generated based on request and order. It tends to follow the common tastes that emphasize aspects of beauty, skill, and uniqueness of a work of art. Besides, the symbolic system as a marker in a work of art, symbolic capital also has important role in forming knowledge system and public appreciation. The symbolic capital is the reputation of artists who are shown through education, achievements, awards, and relationships.

\section{REFERENCES}

[1] Salam, S. Seni Rupa Mimesis dan Modern/Kontemporer di Sulawesi Selatan, Dewan Kesenian Sulawesi Selatan, Makassar, 2000.

[2] Bourdieu, P. The Field of Cultural Production: Essays on Art and Leissure, Columbia University Press, New York, 1993.

[3] Jameson, F. Postmodernism, or, the Cultural Logic of Late Capitalism, Duke University Press, UK, 1991.

[4] Rohidi, T. R. Ekspresi Seni Orang Miskin: Adaptasi SimbolikTerhadap Kemiskinan, Penerbit Nuansa, Bandung, 2000. 
[5] Rohidi, T. R. Segmentasi Identitas dalam Dunia Seni Rupa, Paper on Cultural Arts National Seminar, Makassar, 2017.

[6] Spradley, J. P. Metode Etnografi, PT. Tiara Wacana, Yogyakarta, 1997.

[7] Geertz, C. The Interpretation of Culture, Basic Books, New York, 1973.

[8] Piliang, Y. A. Dunia yang Dilipat: Tamasya Melampaui Batas-batas Kebudayaan. Penerbit Matahari, Bandung, 2011.

[9] Feldman, E. B. Art as Image and Idea, Prentice-Hall, Inc, New Jersey, 1967.

[10] Bourdieu, P. A Social Critique of the Judgment of Taste, Harvard University Press, Cambridge, 1984. 